\title{
Implementasi Six Sigma dalam Peningkatan Kualitas Proses Produksi LED TV di PT Sharp Electronics Indonesia
}

\author{
Phengky Pangestu*) dan Fakhrina Fahma \\ Laboratorium Sistem Kualitas, Fakultas Teknik, Universitas Sebelas Maret, Jl. Ir. Sutami 36A, Surakarta, 57126, \\ Indonesia
}

DOI: 10.20961/performa.17.2.30178

\begin{abstract}
Abstrak
Persaingan industri elektronik di Indonesia sangat ketat sehingga mendorong industri untuk saling bersaing antara satu dengan yang lainnya. PT Sharp Electronics Indonesia sebagai salah satu perusahaan yang memproduksi televisi khususnya Light Emitting Diode (LED) TV sering mengalami masalah terkait kualitas, yaitu masih banyaknya defect yang terjadi pada proses produksi. Berdasarkan perhitungan nilai rata-rata DPMO (defects per million opportunities) dan nilai rata-rata sigma pada bulan Januari 2019 berturut-turut sebesar 672,67 dan 4,71. Indeks kapabilitas proses $\left(C_{p k}\right)$ produksinya sebesar 1,07724. Tujuan dari penelitian ini adalah menurunkan jumlah defect pada pabrik televisi PT Sharp Electronics Indonesia dengan menggunakan Six Sigma melalui tahapan Define, Measure, Analyze, Improve, dan Control (DMAIC). Perbaikan kualitas ini disimulasikan dengan simulasi Monte Carlo yang dibagi menjadi 3 skenario keberhasilan solusi (berkurangnya jumlah defect jenis no raster, no picture, dan no power). Nilai $C_{p k}$ pada hasil simulasi mengalami peningkatan masing-masing menjadi sebesar 1,1; 1,11; dan 1,12.
\end{abstract}

Kata kunci: defect, DMAIC, LED TV, six sigma

\begin{abstract}
Competition in the electronic industry in Indonesia is very tight, which encourages industries to compete with each other. PT Sharp Electronics Indonesia as one of the companies that produce television, especially Light Emitting Diode (LED) $T V$, often has problems related to quality, which are still many defects that occur in the production process. Based on the calculation of the DPMO (defects per million opportunities) average value and the sigma average value in January 2019, it was 672.67 and 4.71 respectively. The process capability index (Cpk) of production is 1.07724. The purpose of this study is to reduce the number of defects in PT Sharp Electronics Indonesia television factories using Six Sigma through the Define, Measure, Analyze, Improve, and Control (DMAIC) stages. This quality improvement is simulated with a Monte Carlo simulation which is divided into 3 scenario success solutions (reduced number of no raster, no picture and no power defects). The Cpk value in the simulation results increases to 1.1; 1.11; and 1.12.
\end{abstract}

Keywords: defect, DMAIC, LED TV, six sigma

\section{Pendahuluan}

Industri perakitan televisi merupakan salah satu sektor industri besar dan sedang Indonesia yang mengalami penurunan produksi tertinggi dibandingkan sektor industri lainnya. Berdasarkan Badan Pusat Statistik (2019), sektor industri komputer, barang elektronik, dan optik mengalami penurunan produksi ( $y$-ony) sebesar 16,87\% pada tahun triwulan IV-2018 terhadap triwulan IV-2017. Namun, menurut Statista (2019) penetrasi pengguna consumer electronics di Indonesia, termasuk produk televisi di dalamnya, sebesar 17,9\% pada tahun 2019 dan diprediksi akan mencapai 24,8\% pada tahun 2023 di mana penggunanya didominasi oleh kalangan menengah ke atas.

Situasi perkembangan televisi saat ini mendorong setiap industri perakitan televisi saling bersaing antara satu dengan yang lainnya. Upaya perusahaan dalam menghadapi situasi tersebut adalah tetap berusaha untuk memberikan kepuasan kepada pelanggan karena keunggulan suatu produk dapat diukur dari tingkat kepuasan pelanggan itu sendiri. Segala sesuatu yang dapat memenuhi keinginan ataupun pelanggan (meeting the needs of customer) adalah salah satu definisi kualitas yang bersifat strategik (Gaspersz, 2005). 
Kualitas pada industri manufaktur tidak hanya terfokus pada produk yang dihasilkan, melainkan juga kualitas pada proses produksi (Ariani, 2003). Proses produksi yang berkualitas dapat dicapai dengan memperkecil variasi yang terjadi (Dewi, 2012). Oleh karena itu, dibutuhkan pengendalian dan peningkatan kualitas pada proses produksi agar produk yang dihasilkan dapat terjaga kualitasnya dan keinginan pelanggan terpenuhi. Hal tersebut dapat dicapai dengan penentuan metode-metode yang digunakan, termasuk teknikteknik statistika dan lainnya (Gaspersz, 2003). Pengendalian dan peningkatan kualitas ini diharapkan dapat meningkatkan efektivitas pengendalian dalam mencegah terjadinya produk cacat pada produksi sehingga pemborosan sumber daya dapat dihindarkan.

PT Sharp Electronics Indonesia sebagai salah satu perusahaan elektronik di bawah Sharp Corporation yang bergerak di bidang perakitan produk elektronik. Salah satu produk yang diproduksi yaitu LED TV. Proses produksi tersebut memiliki beberapa masalah terkait dengan kualitas, yaitu masih sering dijumpai gejala defect pada lini perakitan. Hal tersebut menimbulkan adanya cost of poor quality dikarenakan apabila terjadi defect maka part tersebut harus dilakukan rework ataupun part tersebut dibuang. Jika tidak dilakukan pengendalian kualitas pada hal tersebut dapat mengakibatkan kerugian bagi perusahaan. Berkaitan dengan permasalahan tersebut, perlu dilakukannya perbaikan kualitas secara menyeluruh untuk meminimalkan jumlah defect dan meningkatkan kualitas produk.

Six Sigma adalah suatu metodologi peningkatan berkelanjutan (continuous improvement) yang berfokus pada pelanggan di mana dapat meminimalkan cacat dan variasi hingga 3,4 defects per million opportunities dalam desain produk, produksi, dan proses administrasi (Valles, Sanchez, Noriega, \& Nunez, 2009). Six sigma berbeda dengan metode pengendalian kualitas lainnya karena metode ini tidak hanya sekedar meningkatkan performansi, melainkan juga metode untuk merubah budaya korporasi dari atas hingga ke bawah (Thomsett, 2005). Selain itu, six sigma melibatkan penggunaan alat statistik dengan metodologi terstruktur untuk memperoleh proses yang lebih baik, cepat, dan murah (Breyfogle III, 2003). Pendekatan Six Sigma yang terstruktur dan berkelanjutan mampu memberikan kemudahan dalam mengukur pencapaian perbaikan kualitas sehingga diharapkan dapat mengidentifikasi penyebab kegagalan yang potensial sekaligus mengurangi defect.

Penelitian-penelitian terdahulu terkait six sigma sudah banyak dilakukan sebelumnya. Deamonita (2018) melakukan pengendalian kualitas untuk meminimalkan produk cacat tas tali batik di PT XYZ di mana terjadi peningkatan nilai sigma dari 3,61 menjadi 4,18. Selain itu, Ahmed dkk. (2018) menerapkan six sigma pada perusahaan industri home appliance dan mampu menurunkan jumlah defect sebesar 4,39\%. Penelitian tersebut memiliki metodologi yang sama yaitu DMAIC dengan studi kasus yang berbeda-beda. Oleh sebab itu, dalam penelitian ini akan dilakukan perbaikan kualitas proses produksi PT Sharp Electronics Indonesia dengan six sigma.

\section{Metode Penelitian}

Penelitian ini menggunakan Six Sigma dalam menyelesaikan masalah yang ada di PT Sharp Electronics Indonesia. Penelitian dibagi menjadi beberapa tahap, yaitu define, measure, analyze, improve, dan control (DMAIC). Penelitian ini tidak melakukan evaluasi terhadap hasil implementasi Six Sigma secara langsung. Oleh sebab itu, sebagai alternatif lainnya dilakukan perbaikan kualitas melalui simulasi Monte Carlo dengan beberapa skenario.

- Tahap define, yaitu mengidentifikasi masalah, mengidentifikasi karakteristik kualitas (critical to quality), dan mengidentifikasi proses dengan diagram SIPOC.

- Tahap measure, yaitu melakukan pengukuran stabilitas proses dengan peta kendali u, melakukan perhitungan nilai DPMO, perhitungan nilai sigma (berdasarkan $z$ score dengan mengizinkan adanya pergeseran sebesar 1,5 $\sigma$ ), dan melakukan pengukuran kapabilitas proses. Rumus untuk menghitung nilai DPMO dan nilai sigma adalah sebagai berikut.

$$
\text { DPMO }=\frac{\text { Total Cacat Produksi }}{\text { Total Produksi } x \text { CTQ }} \times 1.000 .000
$$

$$
\text { Sigma }=\left|z_{\frac{D P M O}{1.000 .000}}\right|+1,5
$$

- Tahap analyze, yaitu menganalisis defect yang paling dominan menggunakan diagram pareto dan menganalisis penyebab defect menggunakan cause effect diagram.

- Tahap improve, yaitu menentukan target nilai DPMO dan sigma, menganalisis risiko melalui failure mode and effect analysis dan melakukan simulasi monte carlo. Pada pembuatan failure mode and effect 
analysis akan menghitung nilai Risk Priority Number (RPN). Nilai RPN tertinggi akan menjadi prioritas untuk diberikan usulan perbaikan. Rumus untuk menghitung nilai RPN adalah sebagai berikut.

$$
R P N=\text { Severity } x \text { Occurence } x \text { Detection }
$$

- Tahap control, yaitu mengendalikan perbaikan-perbaikan yang telah dibuat dengan memberikan beberapa usulan pengendalian kualitas bagi perusahaan. Tanpa adanya pengendalian terhadap hasil perbaikan tersebut, proses perbaikan tidak akan mencapai hasil yang diharapkan.

\section{Hasil dan Pembahasan}

Penelitian dilakukan dengan lima tahap berdasarkan metode Six Sigma (DMAIC) yang digunakan untuk menyelesaikan masalah defect, yaitu tahap define, tahap measure, tahap analyze, tahap improve, dan tahap control.

\subsection{Tahap Define}

Tujuan dari tahap define adalah mendefiniskan cakupan masalah dan mendapatkan informasi mengenai letak permasalahan proses. Langkah-langkah yang dilakukan dalam tahap ini adalah mengidentifikasi karakteristik kualitas (critical to quality) dan mengidentifikasi proses.

Critical To Quality (CTQ) Tree digambarkan untuk mengetahui karakteristik kualitas yang diinginkan oleh pelanggan di mana kepuasan pelanggan menjadi faktor utama dalam parameter CTQ (Antony, Vinodh, \& Gijo, 2016). Selain itu, berfungsi untuk membagi ide atau masalah besar ke dalam komponen lebih kecil, membuat lebih mudah dipahami, dan lebih mudah diatasi (Pyzdek \& Keller, 2003). Karakteristik kualitas ini ditentukan berdasarkan dari kondisi cacat yang terjadi pada produksi dan wawancara dengan manajer production quality assurance.

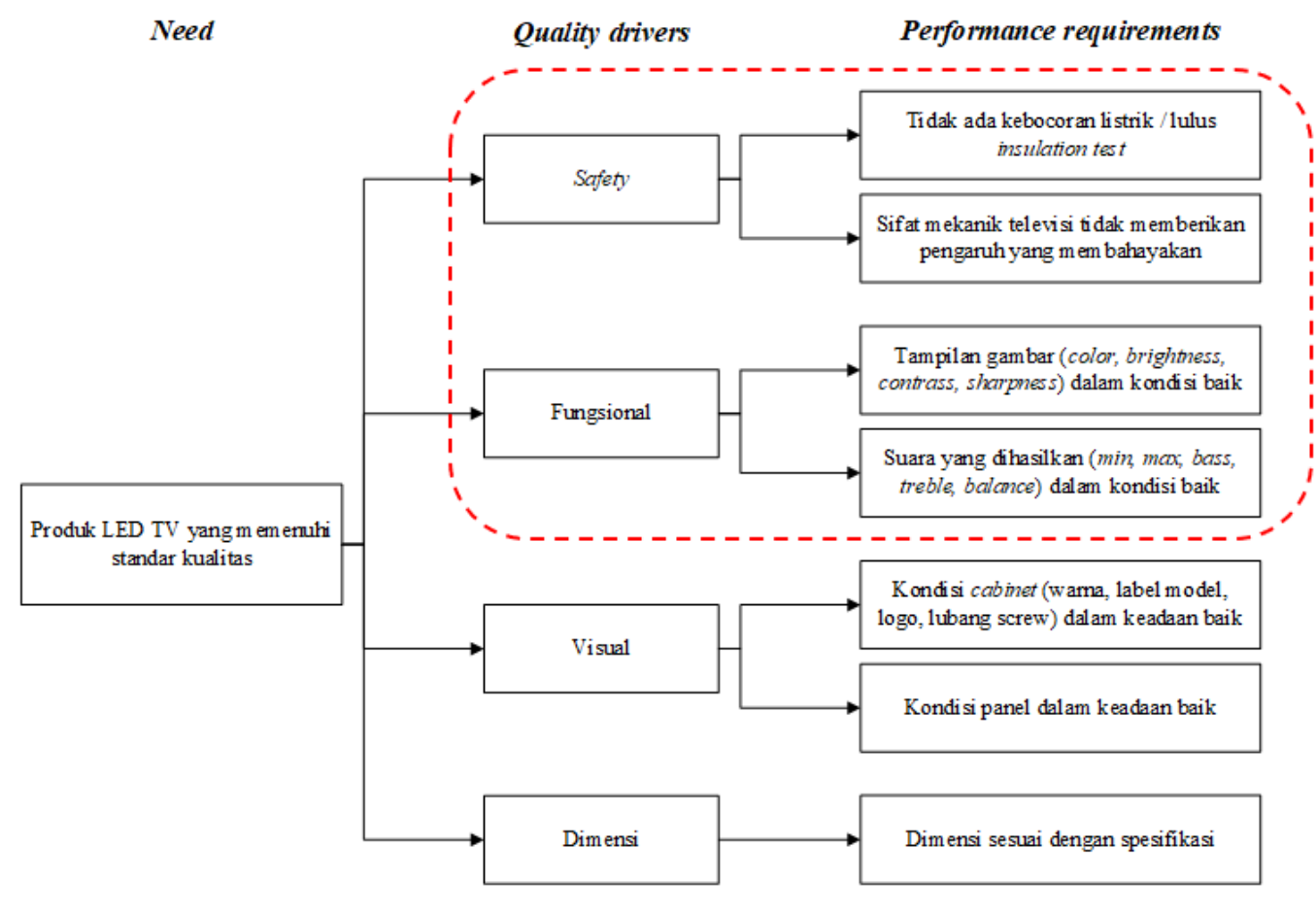

Gambar 1. Critical To Quality (CTQ)

Kemudian, dilakukan identifikasi tahapan proses produksi yang ada. Hal ini dimaksudkan untuk memberi kemudahan dalam memahami proses-proses bisnis dari awal hingga akhir dan berfungsi untuk mengidentifikasi elemen-elemen yang relevan dalam perbaikan proses (process improvement). Alat yang biasa digunakan dalam menggambarkan proses adalah diagram SIPOC (Supplier-Input-Process-OutputCustomer). 


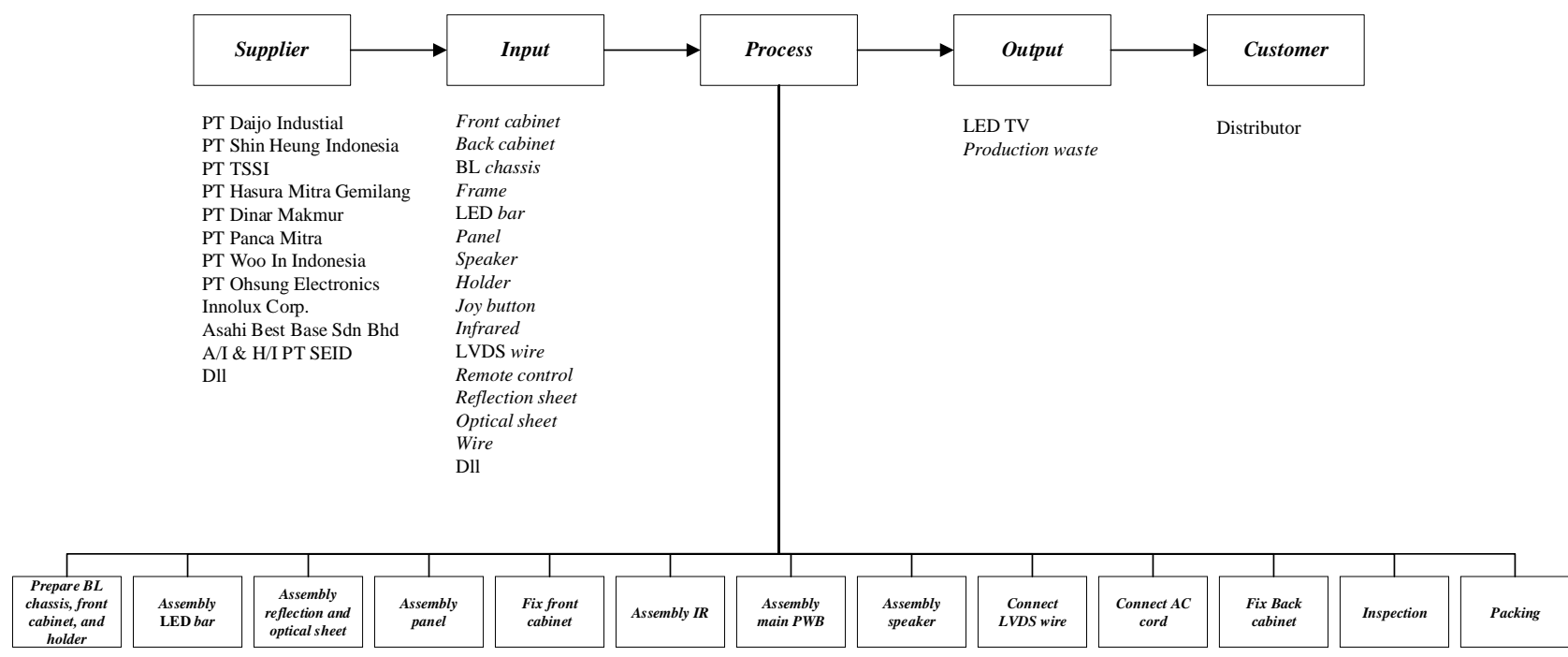

Gambar 2. Diagram SIPOC Proses Produksi LED TV

\subsection{Tahap Measure}

Tujuan dari tahap measure adalah mengukur kemampuan proses kerja dalam menghasilkan output berdasarkan input yang masuk. Langkah-langkah yang dilakukan dalam tahap ini adalah pengukuran stabilitas proses, perhitungan nilai DPMO, nilai sigma, dan pengukuran kapabilitas proses.

Stabilitas proses dilakukan dengan menggunakan peta kendali untuk mengetahui apakah proses berada dalam berada batas-batas kendali atau tidak secara statistik. Peta kendali yang digunakan dalam mengukur kestabilan proses adalah peta kendali u (u-chart). Peta kendali u ini digunakan untuk memantau jumlah defect yang timbul dari produk yang dihasilkan. Selain itu, peta kendali ini khusus dipergunakan untuk ukuran jenis defect produk yang tidak sama serta jumlah produknya tidak konstan.

Tabel 1. Rekapitulasi Jumlah Defect bulan Januari 2019

\begin{tabular}{|c|c|c|c|}
\hline No & Tanggal & $\begin{array}{c}\text { Jumlah } \\
\text { Produksi (unit) }\end{array}$ & Jumlah Defect \\
\hline 1 & $02 / 01 / 19$ & 4530 & 24 \\
\hline 2 & $03 / 01 / 19$ & 4450 & 12 \\
\hline 3 & $04 / 01 / 19$ & 4000 & 13 \\
\hline 4 & $07 / 01 / 19$ & 3924 & 13 \\
\hline 5 & $08 / 01 / 19$ & 4467 & 9 \\
\hline$\cdot$ & $\cdot$ & $\cdot$ & $\cdot$ \\
$\cdot$ & $\cdot$ & $\cdot$ & $\cdot$ \\
\hline 22 & $31 / 01 / 19$ & 4612 & 7 \\
\hline \multicolumn{2}{|c|}{ Total } & $\mathbf{9 9 3 0 1}$ & $\mathbf{2 7 9}$ \\
\hline
\end{tabular}
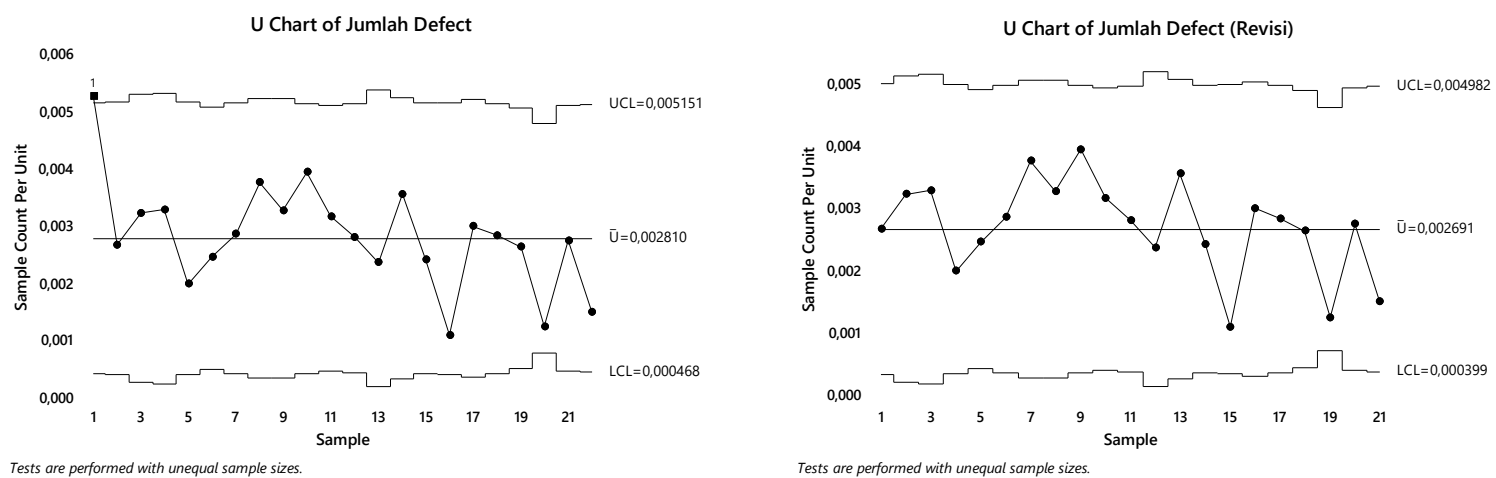

Gambar 3. Peta Kendali u Pada Proses Produksi LED TV bulan Januari 2019 Sebelum dan Sesudah Revisi

Berdasarkan data defect pada proses produksi LED TV bulan Januari 2019 yang telah distabilkan diperoleh jumlah defect sebanyak 255 dari total produksi sebanyak 94.771 unit. Perhitungan nilai sigma mengizinkan adanya pergeseran sebesar 1,5 sigma sedangkan banyaknya opportunity yang digunakan dalam 
156 Performa: Media IImiah Teknik Industri Vol. 17, No. 2

perhitungan nilai sigma adalah sebanyak CTQ yang telah ditentukan yaitu 4 penentu karakteristik kualitas. Perhitungan nilai DPMO dan sigma dengan menggunakan persamaan (1) dan (2) pada setiap periode adalah sebagai berikut.

Contoh:

Tanggal 3 Januari 2019

$D P M O=\frac{\text { Total Defect }}{\text { Total Produksi } \times \text { CTQ }} \times 1.000 .000=\frac{12}{4450 \times 4} \times 1.000 .000=674,16$

Sigma $=\left|z_{\frac{D P M O}{1.000 .000}}\right|+1,5=\left|z_{\frac{674,16}{1.000 .000}}\right|+1,5=4,71$

Tabel 2. Perhitungan Nilai DPMO dan Sigma

\begin{tabular}{|c|c|c|c|c|c|c|}
\hline No. & Tanggal & $\begin{array}{c}\text { Jumlah } \\
\text { Produksi }\end{array}$ & $\begin{array}{c}\text { Jumlah } \\
\text { Defect }\end{array}$ & CTQ & DPMO & Sigma \\
\hline 1 & $03 / 01 / 19$ & 4450 & 12 & 4 & 674,16 & 4,71 \\
\hline 2 & $04 / 01 / 19$ & 4000 & 13 & 4 & 812,50 & 4,65 \\
\hline 3 & $07 / 01 / 19$ & 3924 & 13 & 4 & 828,24 & 4,65 \\
\hline 4 & $08 / 01 / 19$ & 4467 & 9 & 4 & 503,69 & 4,79 \\
\hline 5 & $09 / 01 / 19$ & 4832 & 12 & 4 & 620,86 & 4,73 \\
\hline$\cdot$ & $\cdot$ & $\cdot$ & $\cdot$ & $\cdot$ & $\cdot$ & $\cdot$ \\
$\cdot$ & $\cdot$ & $\cdot$ & $\cdot$ & $\cdot$ & $\cdot$ & $\cdot$ \\
\hline 21 & $31 / 01 / 19$ & 4612 & 7 & 4 & 379,44 & 4,87 \\
\hline \multicolumn{2}{r|}{ Jumlah } & 94771 & 255 & & & \\
\hline \multicolumn{2}{r}{ Nilai Proses } & & & 4 & 672,67 & 4,71 \\
\hline
\end{tabular}
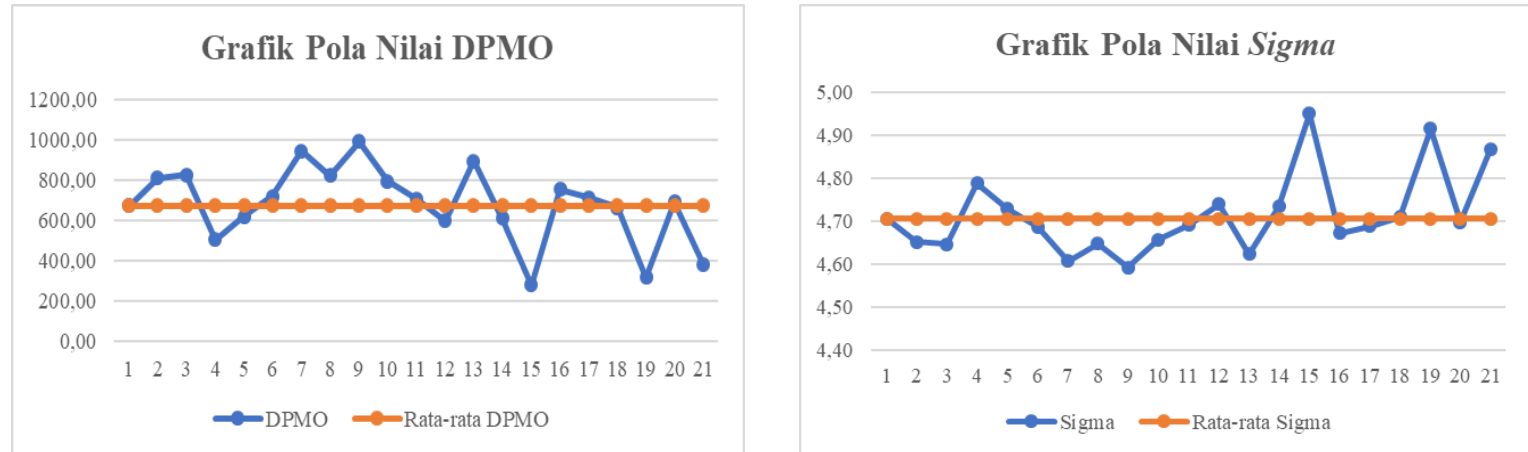

Gambar 4. Grafik Pola Nilai DPMO dan Sigma

Pengukuran kapabilitas proses menggunakan indeks kapabilitas proses $\left(\mathrm{C}_{\mathrm{pk}}\right)$ untuk mengukur kemampuan proses dalam menghasilkan produk yang sesuai dengan kebutuhan konsumen/spesifikasi yang diharapkan. Hal ini dilakukan karena Statistical Process Control tidak mampu menganalisis secara kuantitatif suatu proses yang sedang berjalan, melainkan hanya mampu memantau proses yang sedang berjalan. Penentuan nilai $\mathrm{C}_{\mathrm{pk}}$ menggunakan tabel konversi level sigma sebagai berikut.

Tabel 3. Konversi Level Sigma

\begin{tabular}{|c|c|c|}
\hline \multirow{2}{*}{ Level Sigma } & \multicolumn{2}{|c|}{ Pergeseran Proses $\pm \mathbf{1 , 5} \boldsymbol{\sigma}$} \\
\cline { 2 - 3 } & $\mathbf{C p k}$ & $\mathbf{D P M O}$ \\
\hline 3 & 0,5 & 66.807 \\
\hline 4 & 0,833 & 6.210 \\
\hline 5 & 1,167 & 233 \\
\hline 6 & 1,5 & 3,4 \\
\hline \multicolumn{2}{|c|}{ Sumber: (Mc Fadden, 1993) } \\
\hline
\end{tabular}

Kriteria untuk indeks kapabilitas proses (Mc Fadden, 1993) adalah sebagai berikut.

a. $\quad \mathrm{C}_{\mathrm{pk}} \geq 1,5$; maka proses dianggap mampu dan kompetitif 
b. $0,5 \leq \mathrm{C}_{\mathrm{pk}}<1,5$; maka proses dianggap cukup mampu, namun perlu upaya-upaya giat untuk peningkatan kualitas menuju target yang diinginkan. Perusahaan yang berada di level ini memiliki kesempatan terbaik dalam melakukan program peningkatan kualitas six sigma.

c. $\mathrm{C}_{\mathrm{pk}}<0,5$; maka proses dianggap tidak mampu dan tidak kompetitif untuk bersaing dipasar global

Perhitungan nilai indeks kapabilitas proses $\left(\mathrm{C}_{\mathrm{pk}}\right)$ diperoleh dari hasil interpolasi pada Tabel 3 dengan nilai sigma sebesar 4,71. Perhitungannya adalah sebagai berikut.

$$
\begin{gathered}
\frac{4,71-4}{5-4}=\frac{x-0,833}{1,167-0,833} \\
\frac{0,71}{1}=\frac{x-0,833}{0,334} \\
x=(0,71 \times 0,344)+0,833 \\
x=1,07724 \text { (cukup mampu) }
\end{gathered}
$$

Berdasarkan perhitungan di atas, dapat diketahui bahwa nilai $\mathrm{C}_{\mathrm{pk}}$ yang diperoleh sebesar 1,07724 dan dapat disimpulkan bahwa kemampuan proses produksi LED TV cukup mampu karena dalam rentang 0,5 $\leq$ $\mathrm{C}_{\mathrm{pk}}<1,5$. Kendati demikian, perlu upaya-upaya perbaikan untuk meningkatkan kualitas karena pada level ini ada kesempatan terbaik dalam melakukan program peningkatan kualitas six sigma.

\subsection{Tahap Analyze}

Tujuan dari tahap analyze adalah mengidentifikasi penyebab permasalahan dan mengonfirmasinya dengan menggunakan tools analisis data yang sesuai. Langkah-langkah yang dilakukan dalam tahap ini adalah menganalisis defect yang paling dominan dengan menggunakan diagram pareto dan menganalisis penyebab defect dengan menggunakan cause effect diagram.

Analisis jenis defect yang paling dominan menggunakan diagram pareto di mana diagram ini membantu mengurutkan dan memilah defect yang vital / prioritas dari beberapa defect yang ada pada bulan Januari 2019.

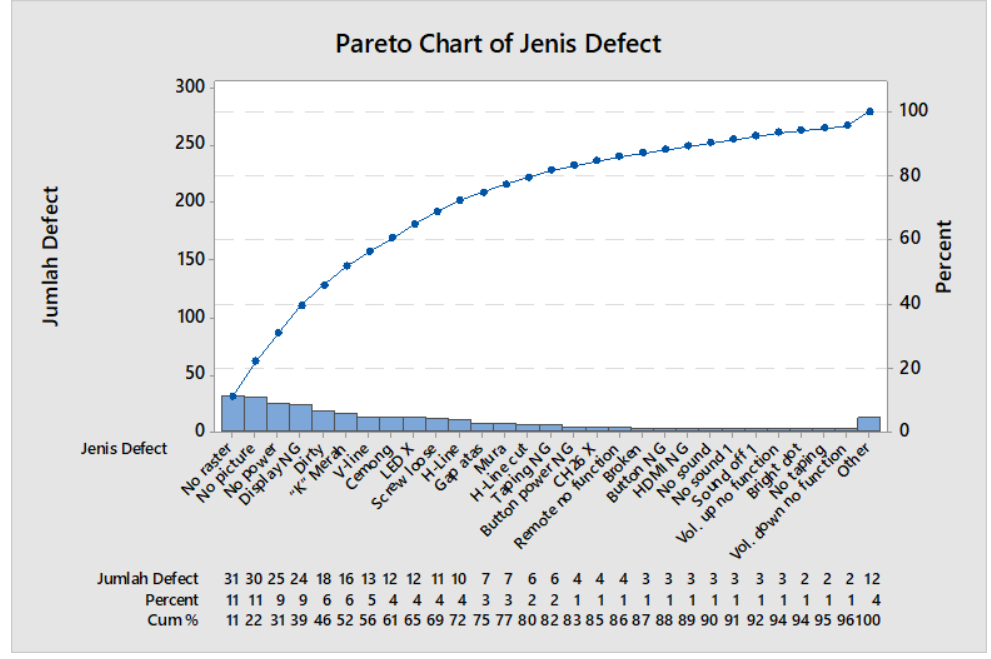

Gambar 5. Diagram Pareto Jenis Defect bulan Januari 2019

Berdasarkan rekapitulasi data yang dilakukan terdapat 39 jenis defect pada bulan Januari 2019. Jenis defect yang mendominasi adalah no raster sebanyak 31 (11,11\%), no picture sebanyak 30 (10,75\%), dan no power sebanyak 25 (8,96\%). Persentase kumulatif ketiga cacat tersebut sebesar 30,82\%. Berdasarkan prinsip pareto yang menyatakan bahwa sekitar $80 \%$ efek dari banyak kejadian disebabkan oleh $20 \%$ dari penyebabnya maka sebenarnya hanya dua jenis defect dominan dengan jumlah kumulatif $21,86 \%$ yang dijadikan prioritas perbaikan. Namun, jenis defect no raster, no picture, dan no power memiliki sedikit kesamaan pada letak permasalahannya sehingga pada penelitian ini dilakukan tindakan perbaikan pada ketiga jenis defect dominan tersebut.

Tabel 4. Defect Dominan bulan Januari 2019

\begin{tabular}{|c|c|c|c|}
\hline Jenis Defect & $\begin{array}{c}\text { Lampu Indikator } \\
\text { (Inframerah) }\end{array}$ & LED & Hiraki \\
\hline No raster & $\checkmark$ & $X$ & $\checkmark$ \\
\hline No picture & $\checkmark$ & $\checkmark$ & $X$ \\
\hline No power & $X$ & $X$ & $X$ \\
\hline
\end{tabular}

Keterangan: $(\checkmark)$ menunjukkan kondisi menyala; $(X)$ menunjukkan kondisi tidak menyala 
No raster adalah cacat yang tidak menampilkan sinar sama sekali di layar televisi yang ditandai dengan komponen LED tidak menyala namun lampu indikator (inframerah) dalam kondisi menyala. No picture adalah cacat di mana layar televisi tidak menampilkan gambar sama sekali yang ditandai dengan komponen hiraki tidak berfungsi atau mengalami kerusakan namun lampu indikator (inframerah) dalam kondisi menyala. Berbeda dengan no power, cacat ini diindikasikan tidak adanya sumber arus ke televisi ditandai dengan tidak menyalanya lampu indikator (inframerah), LED, dan hiraki.

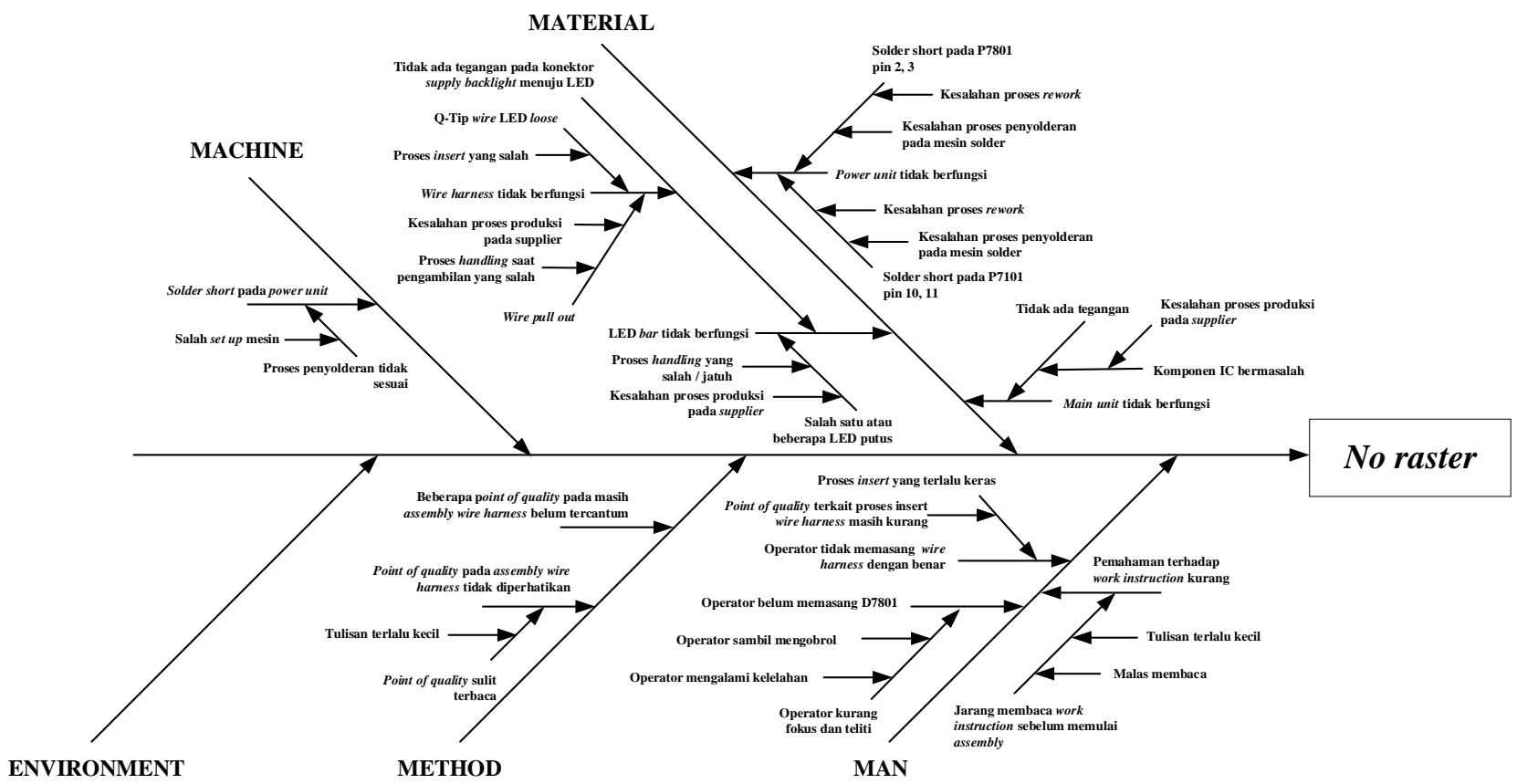

Gambar 6. Cause Effect Diagram Penyebab Terjadinya No Raster

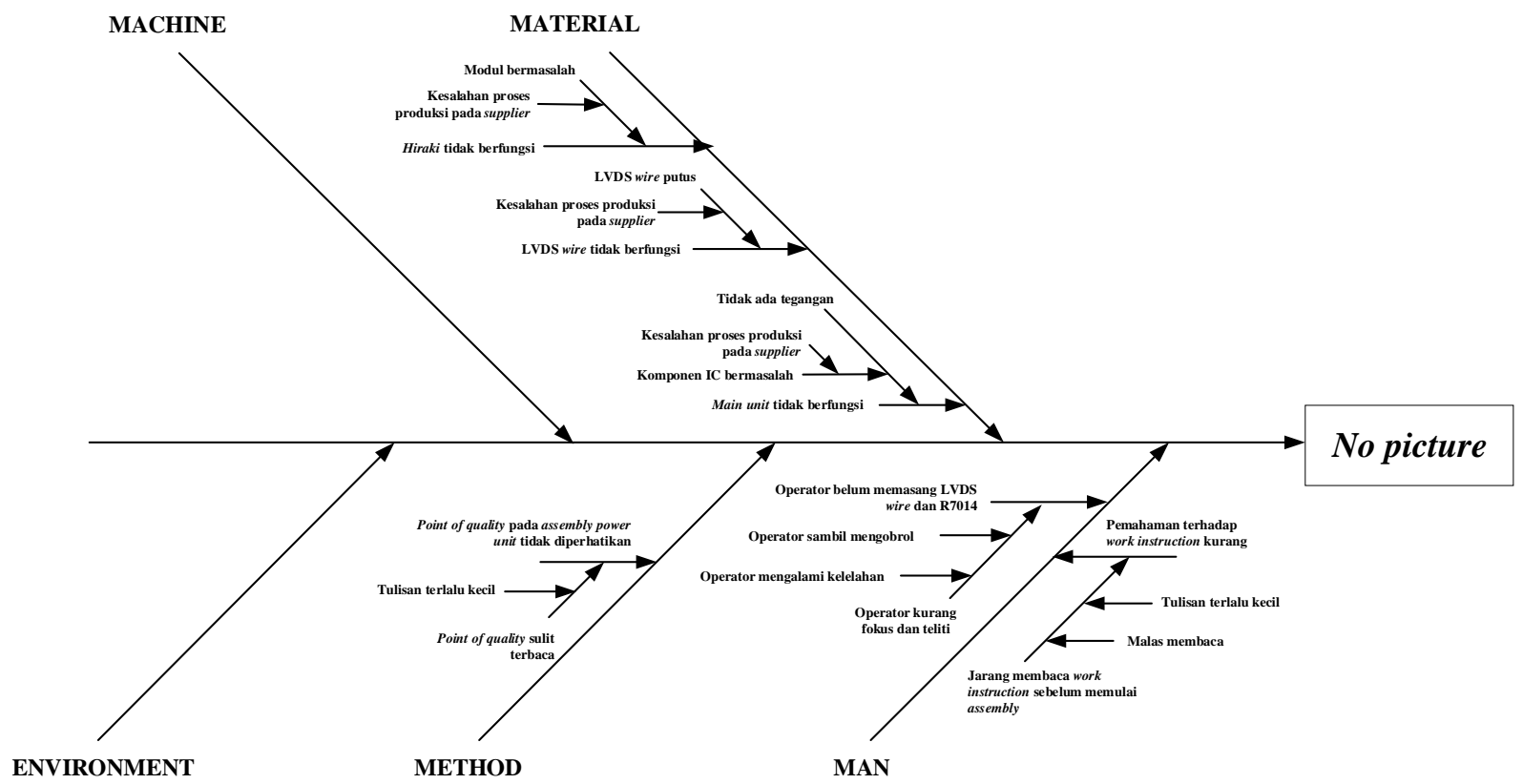

Gambar 7. Cause Effect Diagram Penyebab Terjadinya No Picture 


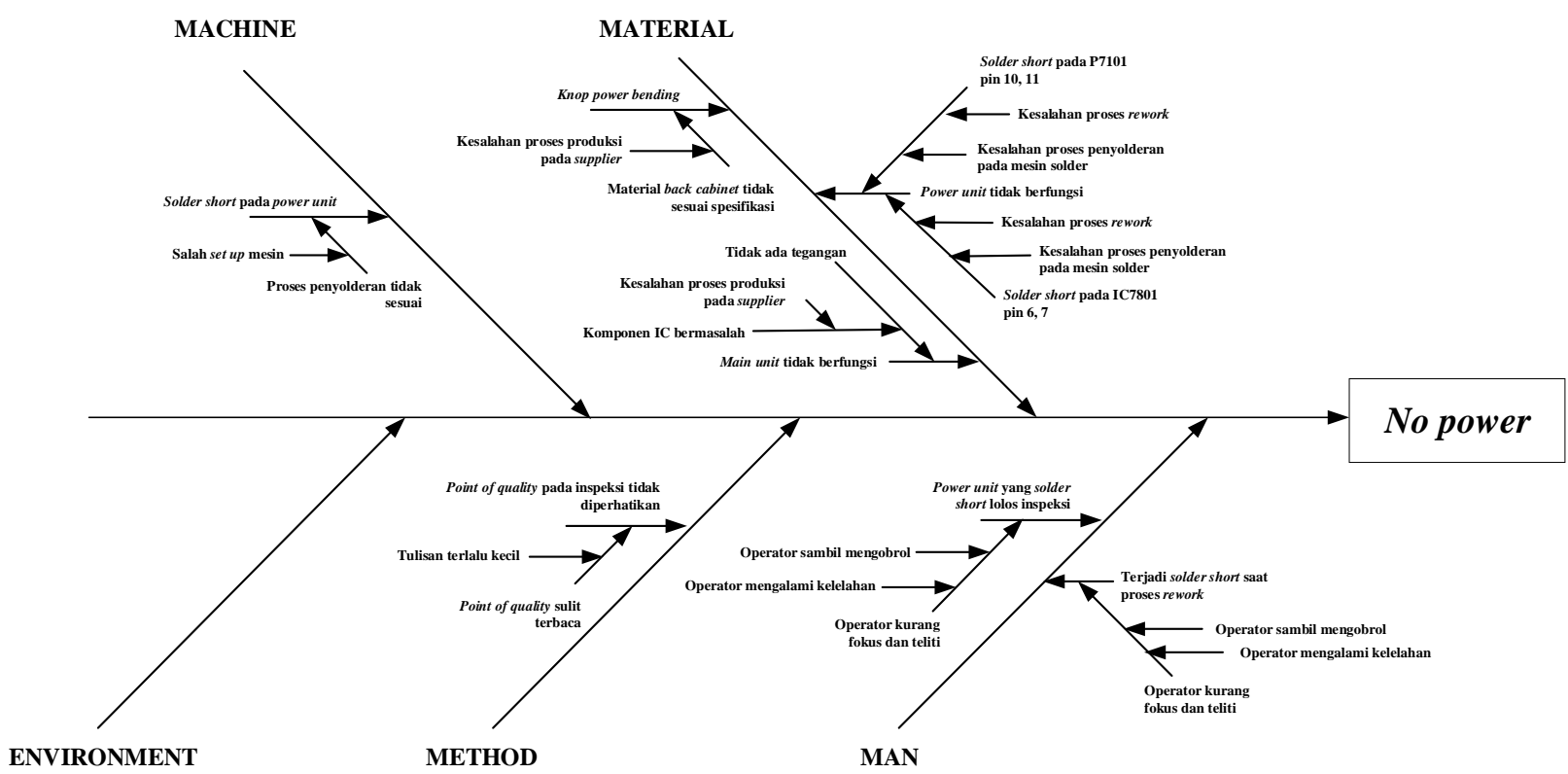

Gambar 8. Cause Effect Diagram Penyebab Terjadinya No Power

\subsection{Tahap Improve}

Tujuan dari tahap improve adalah menetapkan rencana tindakan perbaikan pada proses produksi LED TV untuk menghilangkan akar-akar penyebab permasalahan dan mencegah permasalahan tersebut terulang kembali.

Rencana tindakan perbaikan ini menggunakan tools Failure Mode and Effect Analysis (FMEA). FMEA merupakan alat untuk mengidentifikasi dan menilai risiko yang berhubungan dengan potensial kegagalan sehingga dapat menjadi pertimbangan sebagai prioritas tindakan perbaikan. Penilaian risiko ini dilakukan dengan memberikan nilai pada masing-masing faktor, yaitu severity, occurrence, dan detection (Kubiak \& Benbow, 2009). Setelah dilakukan penilaian risiko, maka dapat ditentukan probabilitas konsekuensi setiap penyebab defect melalui besarnya nilai Risk Priority Number (RPN) dengan menggunakan persamaan (3).

Tabel 5. Failure Mode and Effect Analysis

\begin{tabular}{|c|c|c|c|c|c|c|c|c|c|}
\hline \\
\hline $\begin{array}{l}\text { Input } \\
\text { Proses }\end{array}$ & $\begin{array}{c}\text { Mode } \\
\text { Kegagalan } \\
\text { Potensial }\end{array}$ & $\begin{array}{c}\text { Akibat } \\
\text { Potensial dari } \\
\text { Kegagalan }\end{array}$ & $\mathbf{S}$ & $\begin{array}{l}\text { Penyebab } \\
\text { Potensi } \\
\text { Kegagalan }\end{array}$ & O & $\begin{array}{l}\text { Metode } \\
\text { Deteksi }\end{array}$ & D & RPN & $\begin{array}{l}\text { Tindakan yang } \\
\text { direkomendasikan }\end{array}$ \\
\hline $\begin{array}{c}\text { Main } \\
\text { unit }\end{array}$ & $\begin{array}{l}\text { Tidak ada } \\
\text { tegangan }\end{array}$ & $\begin{array}{l}\text { Main unit tidak } \\
\text { berfungsi }\end{array}$ & 9 & $\begin{array}{l}\text { Komponen } \\
\text { IC } \\
\text { bermasalah }\end{array}$ & 3 & Visual & 8 & 216 & $\begin{array}{l}\text { Melakukan complain ke } \\
\text { supplier dan meminta } \\
\text { melakukan improvement } \\
\text { proses produksi }\end{array}$ \\
\hline \multirow[t]{2}{*}{$\begin{array}{l}\text { LED } \\
\text { bar }\end{array}$} & \multirow[t]{2}{*}{$\begin{array}{l}\text { Salah satu } \\
\text { atau } \\
\text { beberapa } \\
\text { LED putus }\end{array}$} & \multirow[t]{2}{*}{$\begin{array}{l}\text { LED bar tidak } \\
\text { berfungsi }\end{array}$} & \multirow[t]{2}{*}{9} & $\begin{array}{l}\text { Kesalahan } \\
\text { proses } \\
\text { produksi } \\
\text { pada } \\
\text { supplier }\end{array}$ & 1 & Visual & 9 & 81 & $\begin{array}{l}\text { - Meminta data outgoing } \\
\text { quality control dari } \\
\text { supplier } \\
\text { - Melakukan incoming } \\
\text { quality control ketat } \\
\text { (tidak hanya secara } \\
\text { visual melainkan } \\
\text { pengecekan juga } \\
\text { fungsionalnya } \\
\text { perlu dilakukan) } \\
\text { - Meminta supplier } \\
\text { untuk melakukan } \\
\text { perbaikan proses } \\
\text { dengan kurun waktu } \\
\text { tertentu melakukan } \\
\text { - Selalu terkait } \\
\text { follow up proses pada } \\
\text { perbaikan prom } \\
\text { supplier }\end{array}$ \\
\hline & & & & $\begin{array}{l}\text { Proses } \\
\text { handling } \\
\text { yang salah / }\end{array}$ & 1 & Visual & 6 & 54 & $\begin{array}{l}\text { Membuat visual display } \\
\text { yang berisi penjelasan } \\
\text { dan gambar mengenai }\end{array}$ \\
\hline
\end{tabular}




\begin{tabular}{|c|c|c|c|c|c|c|c|c|c|}
\hline & & & & jatuh & & & & & $\begin{array}{l}\text { proses handling LED bar } \\
\text { yang benar }\end{array}$ \\
\hline \multirow{6}{*}{$\begin{array}{l}\text { Wire } \\
\text { harness }\end{array}$} & $\begin{array}{l}\text { Q-Tip wire } \\
\text { LED loose }\end{array}$ & $\begin{array}{l}\text { Wire harness } \\
\text { tidak berfungsi }\end{array}$ & 9 & $\begin{array}{l}\text { Proses insert } \\
\text { yang salah }\end{array}$ & 2 & Visual & 9 & 162 & $\begin{array}{l}\text { Membuat visual display } \\
\text { yang berisi penjelasan } \\
\text { dan gambar mengenai } \\
\text { proses insert wire harness } \\
\text { yang benar }\end{array}$ \\
\hline & \multirow[t]{2}{*}{ Wire pull out } & \multirow[t]{2}{*}{$\begin{array}{l}\text { Wire harness } \\
\text { tidak berfungsi }\end{array}$} & \multirow[t]{2}{*}{9} & $\begin{array}{l}\text { Kesalahan } \\
\text { proses } \\
\text { produksi } \\
\text { pada } \\
\text { supplier }\end{array}$ & 2 & Visual & 6 & 108 & $\begin{array}{l}\text { - Meminta data outgoing } \\
\text { quality control dari } \\
\text { supplier } \\
\text { - Melakukan incoming } \\
\text { quality control ketat } \\
\text { (tidak hanya secara } \\
\text { visual melainkan } \\
\text { pengecekan } \\
\text { fungsionalnya juga } \\
\text { perlu dilakukan) } \\
\text { - Meminta supplier } \\
\text { untuk melakukan } \\
\text { perbaikan proses } \\
\text { dengan kurun waktu } \\
\text { tertentu } \\
\text { - Selalu melakukan } \\
\text { follow up terkait } \\
\text { perbaikan proses pada } \\
\text { supplier }\end{array}$ \\
\hline & & & & $\begin{array}{l}\text { Proses } \\
\text { handling } \\
\text { yang salah }\end{array}$ & 1 & Visual & 6 & 54 & $\begin{array}{l}\text { Membuat visual display } \\
\text { yang berisi penjelasan } \\
\text { dan gambar mengenai } \\
\text { proses handling wire } \\
\text { harness yang benar }\end{array}$ \\
\hline & $\begin{array}{l}\text { Point of } \\
\text { quality sulit } \\
\text { terbaca }\end{array}$ & $\begin{array}{l}\text { Point of } \\
\text { quality pada } \\
\text { assembly wire } \\
\text { harness tidak } \\
\text { diperhatikan }\end{array}$ & 8 & $\begin{array}{l}\text { Tulisan } \\
\text { terlalu kecil }\end{array}$ & 1 & Visual & 3 & 24 & $\begin{array}{l}\text { Membuat visual display } \\
\text { yang lebih besar untuk } \\
\text { mengingatkan operator } \\
\text { agar lebih memperhatikan } \\
\text { point of quality dalam } \\
\text { assembly wire harness }\end{array}$ \\
\hline & \multirow{2}{*}{$\begin{array}{l}\text { Operator } \\
\text { kurang fokus } \\
\text { dan teliti }\end{array}$} & \multirow{2}{*}{$\begin{array}{l}\text { Operator tidak } \\
\text { memasang } \\
\text { wire dengan } \\
\text { benar }\end{array}$} & 8 & $\begin{array}{l}\text { Operator } \\
\text { mengalami } \\
\text { kelelahan }\end{array}$ & 1 & Visual & 5 & 40 & $\begin{array}{lr}\text { Operator } & \text { sebaiknya } \\
\text { memanfaatkan } & \text { waktu } \\
\text { istirahat semaksimal } \\
\text { mungkin }\end{array}$ \\
\hline & & & & $\begin{array}{l}\text { Operator } \\
\text { bekerja } \\
\text { sambil } \\
\text { mengobrol }\end{array}$ & 1 & Visual & 4 & 32 & $\begin{array}{l}\text { Kepala bagian produksi } \\
\text { bertindak tegas jika ada } \\
\text { operator yang mengobrol }\end{array}$ \\
\hline \multirow[t]{3}{*}{$\begin{array}{c}\text { Power } \\
\text { unit }\end{array}$} & \multirow[t]{2}{*}{ Solder short } & \multirow[t]{2}{*}{$\begin{array}{l}\text { Power unit } \\
\text { tidak berfungsi }\end{array}$} & \multirow[t]{2}{*}{10} & $\begin{array}{l}\text { Kesalahan } \\
\text { setting pada } \\
\text { soldering } \\
\text { machine }\end{array}$ & 1 & Visual & 6 & 60 & $\begin{array}{l}\text { - Membuat SOP } \\
\text { mengenai teknis setting } \\
\text { mesin dengan detail } \\
\text { seperti dipping time, } \\
\text { conveyor speed, } \\
\text { opening pada wave } \\
\text { nozzle, dan ketinggian } \\
\text { wave } \\
\text { - Melakukan dan } \\
\text { memastikan setting } \\
\text { mesin telah dilakukan } \\
\text { dengan tepat }\end{array}$ \\
\hline & & & & $\begin{array}{l}\text { Proses } \\
\text { rework yang } \\
\text { salah }\end{array}$ & 1 & Visual & 5 & 50 & $\begin{array}{l}\text { Membuat visual display } \\
\text { yang berisi penjelasan } \\
\text { dan gambar mengenai } \\
\text { proses rework solder } \\
\text { short yang benar }\end{array}$ \\
\hline & $\begin{array}{l}\text { Point of } \\
\text { quality sulit } \\
\text { terbaca }\end{array}$ & $\begin{array}{l}\text { Point of } \\
\text { quality pada } \\
\text { assembly dan } \\
\text { inspeksi power }\end{array}$ & 8 & $\begin{array}{l}\text { Tulisan } \\
\text { terlalu kecil }\end{array}$ & 1 & Visual & 3 & 24 & $\begin{array}{l}\text { Membuat visual display } \\
\text { yang lebih besar untuk } \\
\text { mengingatkan operator } \\
\text { agar lebih teliti dalam }\end{array}$ \\
\hline
\end{tabular}




\begin{tabular}{|c|c|c|c|c|c|c|c|c|c|}
\hline & & $\begin{array}{l}\text { unit tidak } \\
\text { diperhatikan }\end{array}$ & & & & & & & inspeksi power unit \\
\hline & $\begin{array}{l}\text { Operator } \\
\text { kurang fokus } \\
\text { dan teliti }\end{array}$ & $\begin{array}{l}\text { Power unit } \\
\text { yang solder } \\
\text { short lolos } \\
\text { inspeksi }\end{array}$ & 7 & $\begin{array}{l}\text { Operator } \\
\text { mengalami } \\
\text { kelelahan }\end{array}$ & 1 & Visual & 5 & 35 & $\begin{array}{lr}\text { Operator } & \text { sebaiknya } \\
\text { memanfaatkan } & \text { waktu } \\
\text { istirahat } & \text { semaksimal } \\
\text { mungkin } & \\
\end{array}$ \\
\hline Hiraki & $\begin{array}{l}\text { Modul } \\
\text { bermasalah }\end{array}$ & $\begin{array}{l}\text { Hiraki tidak } \\
\text { berfungsi }\end{array}$ & 9 & $\begin{array}{l}\text { Kesalahan } \\
\text { proses } \\
\text { produksi } \\
\text { pada } \\
\text { supplier }\end{array}$ & 1 & Visual & 9 & 81 & $\begin{array}{l}\text { - Meminta data outgoing } \\
\text { quality control dari } \\
\text { supplier } \\
\text { - Melakukan incoming } \\
\text { quality control ketat } \\
\text { (tidak hanya secara } \\
\text { visual melainkan } \\
\text { pengecekan } \\
\text { fungsionalnya juga } \\
\text { perlu dilakukan) } \\
\text { - Meminta supplier } \\
\text { untuk melakukan } \\
\text { perbaikan proses } \\
\text { dengan kurun waktu } \\
\text { tertentu } \\
\text { - Selalu melakukan } \\
\text { follow up terkait } \\
\text { perbaikan proses pada } \\
\text { supplier }\end{array}$ \\
\hline \multirow{2}{*}{$\begin{array}{l}\text { LVDS } \\
\text { wire }\end{array}$} & \multirow{2}{*}{$\begin{array}{l}\text { Operator } \\
\text { kurang fokus } \\
\text { dan teliti }\end{array}$} & \multirow{2}{*}{$\begin{array}{l}\text { Operator tidak } \\
\text { memasang } \\
\text { LVDS wire } \\
\text { dengan benar }\end{array}$} & \multirow{2}{*}{8} & $\begin{array}{l}\text { Operator } \\
\text { bekerja } \\
\text { sambil } \\
\text { mengobtol }\end{array}$ & 1 & Visual & 4 & 32 & $\begin{array}{l}\text { Kepala bagian produksi } \\
\text { bertindak tegas jika ada } \\
\text { operator yang mengobrol }\end{array}$ \\
\hline & & & & $\begin{array}{l}\text { Operator } \\
\text { mengalami } \\
\text { kelelahan }\end{array}$ & 1 & Visual & 5 & 40 & $\begin{array}{lr}\text { Operator } & \text { sebaiknya } \\
\text { memanfaatkan } & \text { waktu } \\
\text { istirahat } & \text { semaksimal } \\
\text { mungkin } & \\
\end{array}$ \\
\hline $\begin{array}{c}\text { Back } \\
\text { cabinet }\end{array}$ & $\begin{array}{l}\text { Material } \\
\text { back cabinet } \\
\text { tidak sesuai } \\
\text { spesifikasi }\end{array}$ & $\begin{array}{l}\text { Knop power } \\
\text { bending }\end{array}$ & 10 & $\begin{array}{l}\text { Kesalahan } \\
\text { proses } \\
\text { produksi } \\
\text { pada } \\
\text { supplier }\end{array}$ & 2 & Visual & 9 & 180 & $\begin{array}{l}\text { - Meminta data } \text { outgoing } \\
\text { quality control dari } \\
\text { supplier } \\
\text { - Melakukan incoming } \\
\text { quality control ketat } \\
\text { (tidak hanya secara } \\
\text { visual melainkan } \\
\text { pengecekan } \\
\text { fungsionalnya juga } \\
\text { perlu dilakukan) } \\
\text { - Meminta supplier } \\
\text { untuk melakukan } \\
\text { perbaikan proses } \\
\text { dengan kurun waktu } \\
\text { tertentu } \\
\text { - Selalu melakukan } \\
\text { follow up terkait } \\
\text { perbaikan proses pada } \\
\text { supplier }\end{array}$ \\
\hline
\end{tabular}

Berdasarkan data defect yang ada, dilakukan simulasi Monte Carlo untuk meniru defect yang dihasilkan pada sistem proses produksi. Simulasi ini menghitung nilai-nilai secara acak dari variabel yang tidak pasti dengan berulang-ulang. Perhitungan yang berulang-ulang digunakan untuk mendapatkan distribusi probabilitas dari model yang disimulasikan. Simulasi ini dilakukan pada performa saat ini, skenario 1 keberhasilan solusi 50\%, skenario 2 - keberhasilan solusi 70\%, dan skenario 3 - keberhasilan solusi $100 \%$. Keberhasilan solusi yang dimaksud adalah hanya berkurangnya jumlah defect jenis no raster, no picture, dan no power yang menjadi defect dominan di PT Sharp Electronics Indonesia. Tiap kondisi simulasi dilakukan dengan iterasi sebanyak 50.000 kali. 
DPMO

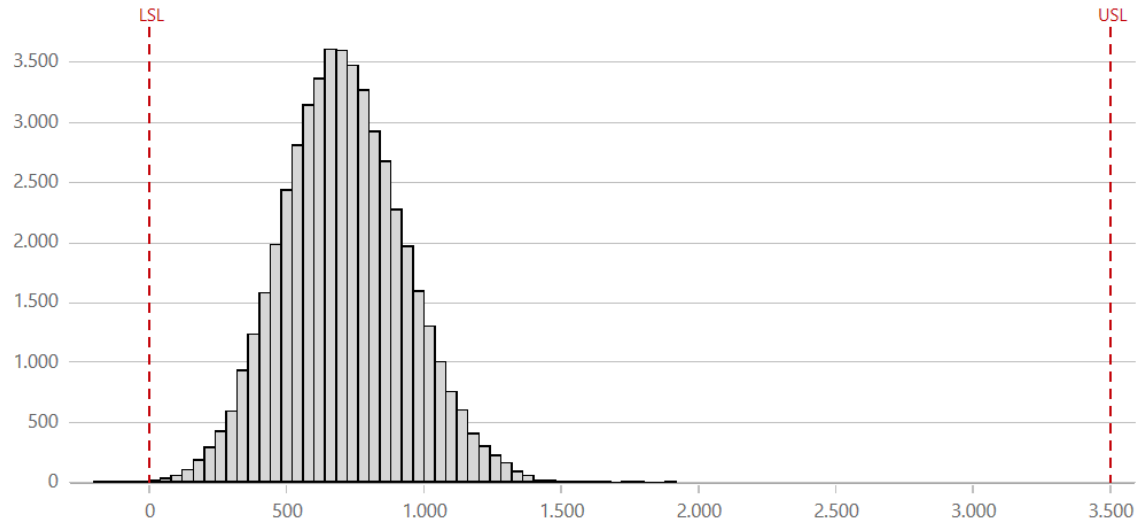

Process Performance (Cpk)

1,07

\% Out of Spec

$0,06 \%$

\begin{tabular}{lr}
\multicolumn{2}{c}{ Summary Statistics } \\
\hline N & 50.000 \\
Mean & 709,519 \\
Standard Deviation & 227,08
\end{tabular}

Gambar 9. Hasil Simulasi Performansi Saat Ini

DPMO

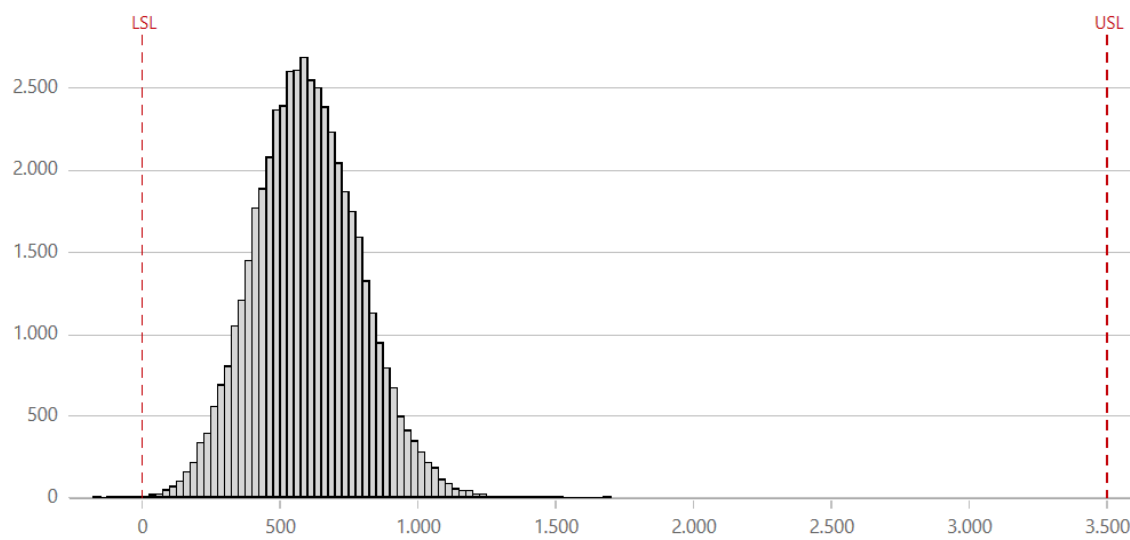

Process Performance (Cpk)

1,1

\% Out of Spec

$0,04 \%$

Gambar 10. Hasil Simulasi Performansi Skenario 1 - Keberhasilan Solusi 50\%

DPMO

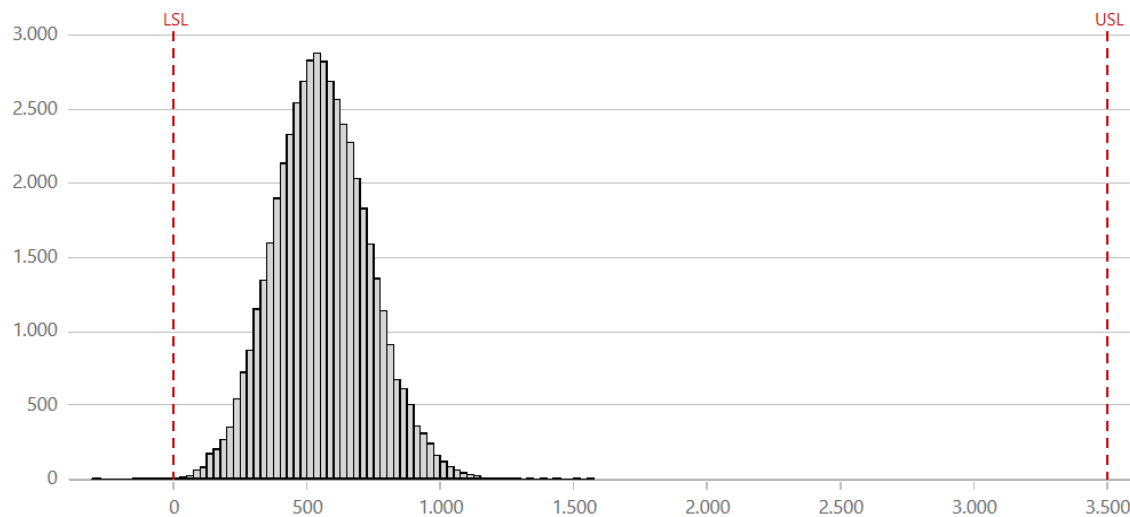

Process Performance (Cpk)

1,11

\% Out of Spec

$0,05 \%$

\begin{tabular}{lr}
\multicolumn{2}{c}{ Summary Statistics } \\
\hline N & 50.000 \\
Mean & 556,261 \\
Standard Deviation & 177,979
\end{tabular}

Gambar 11. Hasil Simulasi Performansi Skenario 2 - Keberhasilan Solusi 70\%

DPMO

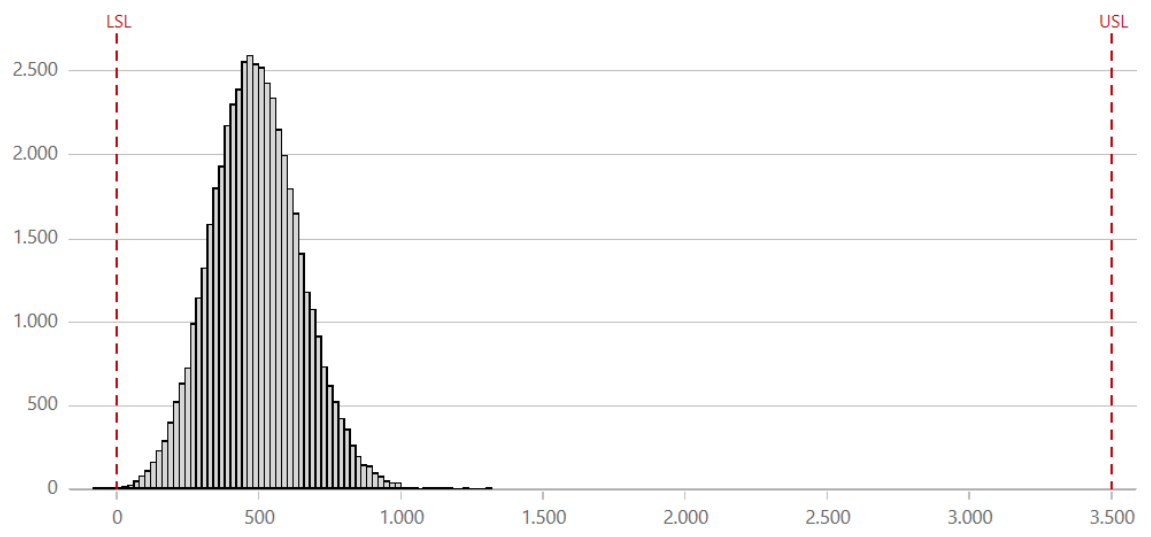

Process Performance (Cpk)

1,12

\% Out of Spec

$0,03 \%$

\begin{tabular}{lr}
\multicolumn{2}{c}{ Summary Statistics } \\
\hline N & 50.000 \\
Mean & 490,811 \\
Standard Deviation & 157,468
\end{tabular}

Gambar 12. Hasil Simulasi Performansi Skenario 3 - Keberhasilan Solusi 100\% 
Berdasarkan hasil simulasi, terlihat bahwa setiap keberhasilan akan membawa dampak positif terhadap perusahaan di mana dapat dilihat dari meningkatnya indeks kapabilitas proses. Skenario 3 merupakan skenario yang terbaik di mana memberikan indeks kapabilitas proses tertinggi dengan nilai sebesar 1,12. Hal ini membuktikan bahwa solusi tersebut akan memberikan peningkatan kualitas terhadap perusahaan. Tetapi tetap tergantung dari kontrol yang dilakukan untuk upaya meminimalkan variasi yang terjadi.

\subsection{Tahap Control}

Tujuan dari tahap control adalah mengendalikan perbaikan-perbaikan yang telah dibuat pada tahap improve. Tanpa adanya pengendalian terhadap hasil perbaikan tersebut, proses perbaikan tidak akan mencapai hasil yang diharapkan. Adapun control atau pengendalian yang dilakukan adalah sebagai berikut.

1. Memantau dan memastikan proses produksi dalam kondisi terkendali dengan melakukan perhitungan nilai sigma secara periodik.

2. Melakukan rekam data perbaikan sehingga dapat dilakukan perbandingan proses perbaikan saat ini dengan sebelumnya. Tools yang dapat digunakan antara lain check sheet, peta kendali, dan pendokumentasian.

3. Memantau perkembangan proses perbaikan yang dilakukan oleh supplier agar perbaikan tersebut dapat kembali memenuhi spesifikasi part yang diinginkan.

4. Melakukan pengawasan yang ketat pada setiap point of quality proses LED TV assembly.

5. Selalu memperbarui work instruction dan point of quality.

6. Inspeksi pada incoming quality control mengacu pada prosedur MIL-STD 105E dengan kriteria general inspection II dan AQL sebesar 0,65.

\section{Simpulan}

Pada lini produksi LED TV terdapat 39 jenis defect yang terjadi pada bulan Januari 2019. Berdasarkan pehitungan persentase, defect yang dominan adalah jenis no raster, no picture, dan no power dengan persentase defect masing-masing sebesar 11,11\%; 10,75\%; dan 8,96\%. Ketiga defect tersebut memiliki persamaan dan perbedaan pada kondisi standby, LED, dan hiraki.

Berdasarkan cause effect diagram, diketahui penyebab terjadinya defect no raster adalah LED bar, power unit, dan main unit yang tidak berfungsi, dan lain-lain. Pada defect no picture disebabkan oleh hiraki, LVDS wire, dan main unit yang tidak berfungsi, dan lain-lain. Selain itu, defect no power disebabkan oleh knop power bending, main unit tidak berfungsi, power unit tidak berfungsi, dan lain-lain.

Berdasarkan failure mode and effect analysis, diketahui bahwa usulan perbaikan untuk defect jenis no raster adalah melakukan complain kepada supplier dan meminta untuk melakuakn improvement pada proses produksinya. Usulan perbaikan untuk defect jenis no picture adalah meminta data outgoing quality control dari supplier sebagai bukti bahwa supplier sudah melakukan inspeksi dan melakukan incoming quality control yang ketat (tidak hanya inspeksi secara visual melainkan pengecekan fungsional juga perlu dilakukan). Selain itu, meminta supplier untuk melakukan perbaikan proses produksi dalam kurun waktu tertentu dan selalu melakukan follow up terkait perbaikan proses tersebut. Usulan perbaikan untuk defect jenis no power adalah membuat visual display yang berisi penjelasan dan gambar mengenai proses insert pada wire harness dengan benar.

Perbaikan kualitas ini disimulasikan dengan simulasi Monte Carlo yang dibagi menjadi 3 skenario keberhasilan solusi (berkurangnya jumlah defect jenis no raster, no picture, dan no power). Nilai $\mathrm{C}_{\mathrm{pk}}$ pada hasil simulasi mengalami peningkatan masing-masing menjadi sebesar 1,1; 1,11; dan 1,12. Berdasarkan hasil simulasi, terlihat bahwa setiap keberhasilan akan membawa dampak positif terhadap perusahaan di mana dapat dilihat dari meningkatnya indeks kapabilitas proses. Untuk penelitian selanjutnya, sebaiknya melakukan identifikasi permasalahan kualitas produksi yang mendalam pada supplier di mana masalah tersebut merupakan salah satu penyebab defect yang terjadi di PT Sharp Electronics Indonesia.

\section{Daftar Pustaka}

Ahmed, N. G., Abohashima, H. S., \& Aly, M. F. (2018). Defect Reduction Using Six Sigma Methodology in Home Appliances Company: A Case Study. Proceedings of the International Conference on Industrial Engineering and Operations Management, 1349-1358.

Antony, J., Vinodh, S., \& Gijo, E. V. (2016). Lean Six Sigma for Small and Medium Sized Enterprise A Practical Guide. Boca Raton: CRC Press.

Ariani, D. W. (2003). Manajemen Kualitas Pendekatan Sisi Kualitatif. Jakarta: Ghalia Indonesia.

Badan Pusat Statistik. (2019, Februari 1). Pertumbuhan Produksi IBS Tahun 2018 Naik 4,07 Persen dibandingkan Tahun 2017. Retrieved Februari 16, 2019, from Badan Pusat Statistik: 
https://www.bps.go.id/pressrelease/2019/02/01/1623/pertumbuhan-produksi-ibs-tahun-2018-naik-4-07persen-dibandingkan-tahun-2017.html

Breyfogle III, F. W. (2003). Implementing Six Sigma: Smarter Solutions Using Statistical Methods Second Edition. New Jersey: John Wiley \& Sons, Inc.

Deamonita, A. I., \& Damayanti, R. W. (2018). Pengendalian Kualitas Tas Tali Batik di PT XYZ dengan Menggunakan Metode Six Sigma. Seminar dan Konferensi Nasional IDEC, 161-169.

Dewi, S. K. (2012). Minimasi Defect Produk dengan Konsep Six Sigma. Jurnal Teknik Industri, Vol. 13, No. $1,43-50$.

Gaspersz, V. (2003). Metode Analisis untuk Peningkatan Kualitas. Jakarta: PT Gramedia Pustaka Utama.

Gaspersz, V. (2005). Total Quality Management. Jakarta: PT Gramedia Pustaka Utama.

Kubiak, T. M., \& Benbow, D. W. (2009). The Certified Six Sigma Blackbelt Handbook. Milwaukee: ASQ Quality Press.

Mc Fadden, F. R. (1993). Six Sigma Quality. Quality Press, 37-42.

Pulido, H. G., \& Salazar, R. d. (2004). Control Estadístico de Calidad y Seis Sigma. Mexico : McGrawHill/Interamericana Editories, S.A. de C.V.

Pyzdek, T., \& Keller, P. A. (2003). The Six Sigma Handbook. New York: McGraw-Hill.

Statista. (2019, Februari). Consumer Electronics Indonesia. Retrieved Februari 16, 2019, from Statista: https://www.statista.com/outlook/251/120/consumer-electronics/indonesia\#market-globalRevenue

Thomsett, M. C. (2005). Getting Started in Six Sigma. New Jersey: John Wiley \& Sons, Inc.

Valles, A., Sanchez, J., Noriega, S., \& Nunez, B. G. (2009). Implementation of Six Sigma in a Manufacturing Process: A Case Study. International Journal of Industrial Engineering, 171-181.

Wahyuni, H. C., Sulistiyowati, W., \& Khamim, M. (2015). Pengendalian Kualitas: Aplikasi pada Industri Jasa dan Manufaktur dengan Lean, Six Sigma, dan Servqual. Yogyakarta: Graha Ilmu. 